\title{
Lembranças e reflexões sobre Pierre C lastres: entrevista com Bento Prado Júnior ${ }^{1}$
}

\author{
Piero de Camargo Leirner \\ Professor do D epartamento de Ciências Sociais - U FSCar \\ Luiz Henrique deToledo \\ Professor do D epartamento de Ciências Sociais - U FSCar
}

A idéia de entrevistar Bento Prado Júnior, certamente um dos grandes nomes da filosofia atual, veio de uma conversa informal que tivemos com o editor da Revista de Antropologia, José G uilherme M agnani. Ao comentarmos sobre os relançamentos de obras clássicas na antropologia, em especial A sociedade contra o Estado de Pierre Clastres, mencionamos, de passagem, alguns encontros que tivemos com Bento Prado, tanto em uma das reuniões da Anpocs, oportunidade em que o filósofo debateu um paper do antropólogo Eduardo Viveiros de Castro², quanto em outras ocasiões, na própria U niversidade Federal de São C arlos. N essas conversas informais ele pôde fal ar a respeito da possível, e julgamos necessária, relação entrefilosofia e antropologia. M arcou-nos, como saldo dessas conversas, a rel evância de C lastres não só para pensar tal relação, mas também o sentido da universalidade de seu pensamento no que diz respeito à política, à natureza do poder, aos cânones da moderna etnografia e à relação que os antropólogos travam com os nativos, enfim, aos sentidos mais gerais que norteiam a própria antropologia.

Formulamos, então, uma primeira idéia de entrevistá-lo, pensando que tal ocasião, para além de seu testemunho sobre Clastres, também serviria de pretexto para mostrar de maneira mais sistemática algumas 
opiniões sobre seu entendimento da relação entre filosofia e antropologia. Como o leitor verá nas páginas seguintes, suas reflexões ultrapassaram o propósito inicial. Além de sua marca conceitual - própria do filósofo - , o sentido trazido pela experiência pessoal, cultivada na amizade com Clastres, remete-nos fortemente à proximidade entre etnografia, model os teóricos e contexto de pesquisa na produção de conceitos que convergem com a base filosófica ocidental.

Assim, entre casos e reflexões (um tanto) originais, o leitor terá a oportunidade de conhecer um pouco mais de Clastres e, por causa dele mesmo, ol har mais atentamente a antropologia pelo enfoque filosófico. Interessante notar, contudo, que salta aos ol hos um caráter francamente antropológico nas posições de Bento Prado Jr., que, longe de falar do interior de uma redoma disciplinar, mais parece transitar com uma grande simpatia entre a filosofia e a antropologia, podendo em algo assumir os dois pontos de vista ao mesmo tempo. D esse modo, volta-se a nós discutindo, entre outras coisas, a etnografia, o estruturalismo, a cosmologia e uma possível metafísica indígena.

Esse percurso intelectual, rememorado e registrado por nós, ocorreu numa sessão de entrevista em sua casa, em São C arlos, em julho de2003. A partir da transcrição, acrescentamos as notas com as referências citadas e, finalmente, Bento Prado J r. reviu o texto de suas respostas e nelas introduziu várias precisões, tendo, inclusive, redigido uma pequena introdução queaqui segue. A proveitamos, então, para agradecer mais uma vez a extrema gentileza com que nos recebeu e concedeu estas reflexões.

$$
* * *
$$

Agradeço a iniciativa da Revista de Antropologi a e de meus colegas da UFSC ar, que me dão agora a oportunidade de lembrar meu saudoso amigo Pierre Clastres. É certo que sua obra écada vez mais lida e valori- 
zada no Brasil como na França. M as talvez escape ao leitor de hoje algo de essencial em seus escritos - visível apenas entre as névoas das entrelinhas -, mais facilmente accessível para quem com ele conviveu como amigo próximo: aquilo que há de propriamente pessoal e irrepetível no perfil intelectual de Pierre Clastres e que seu estilo ascético e rigoroso tende a esconder.

$\mathrm{O}$ curioso é que há poucos meses, conversando com $\mathrm{H}$ élène $\mathrm{Clas}$ tres, convidei-a para uma visita a nossa universidade em São Carlos. Ela poderia falar, para nós, de sua própria obra - penso aqui, entre outros escritos, no belo livro A Terra sem mal - e da de seu marido, tão essencialmente ligadas uma à outra e reciprocamente iluminadoras. A resposta não foi imediatamente positiva, mas me permito guardar a esperança de poder recebêla em futuro próximo para ouvi-la a respeito desse capítulo tão peculiar do "estruturalismo" francês, especialmente nas décadas de 60 e 70 do século passado, cuja força só aparece plenamente nos dias de hoje.

Achamos interessante, professor, reconstituir um pouco seu primeiro encontro com Pierre e H élène Clastres.

$\mathrm{N}$ a verdade, conheci Pierre antes de $\mathrm{H}$ élène. Foi logo depois da volta de minha primeira viagem à França, em 1963. No segundo semestre desse ano, Fernando H enrique me convidou para conhecer, em sua casa, dois antropólogos franceses que passavam pelo Brasil em direção ao Paraguai: Pierre Clastres e Lucien Sebag. H élène ficara em Paris - ela esperava, se a data acima está certa, o nascimento de seu filho Jean$M$ ichel. Algum tempo depois (dois anos?) foi, com seu filho, encontrar-se com Pierre entre os índios do Paraguai, que deram ao menino 0 belo nome de Baimamá (pequena coisa redonda).

Aliás, não é só a mim que falta a memória. Para estabelecer alguns dados biográficos do autor de A soci edade contra o Estado3n, uma das secre- 
P. de C. Leirner \& L. H. de Toledo. Lembranças e Reflexões sobre...

tárias da editora telefonou-me perguntando a respeito de datas: estadias no Brasil, cursos na USP etc. Telefonei para a H élène em busca de ajuda, mas o seu auxílio foi muito pequeno. 0 s tempos passam...

D e qualquer maneira, a partir da segunda estadia de Pierre, no Brasil, ficamos muito próximos. M uitas manias, teóricas e outras nos eram comuns. Freqüentemente, na rua $M$ aria Antonia, Pierre me perguntava: "que horas são?". D epois de minha resposta, acrescentava: "il faut commémorer cela!". A prendi então al gumas versões do ato da libação em argot, como "se jetter quelque chose derrière la cravate" ou "se picrâter la cervelle". Em 1969, quando fui cassado pelo Al-5 e tive de retornar à França, acabei alugando um apartamento no limite de Paris, entre Vanves e Issy-les-M oulineaux, bem perto do dos Clastres, com quem mantivemos contínua e perfeitamente fraternal convivência até agosto de 1974. Chegamos a passar (eu, Lúcia e nossos filhos) três férias juntos: no Laric, num pequeno castelo do século XVI nosAlpes, de propriedade dos pais de $H$ élène; nas C évennes, numa casa secundária de Pierre e H élène; e na Gasconha, em Boussens, na casa do pai de Clastres. É curioso notar que Pierre, fino escritor, era gascão (como D 'Artagnan) e só veio a aprender o francês na escola. Para mim foi um profundo abalo saber, três anos depois, do acidente que o levou à morte.

Ele lecionou na U niversidade de São Paulo quando veío para cá?

Se não me engano, lecionou formalmente em sua segunda estadia em 1967, pelo menos, já que em maio de 68 já estava empenhado em construir sólidas barricadas nos bulevares de Paris. $M$ as antes de suas atividades docentes pude ouvir uma exposição sua, informal, no apartamento de Gérard Lebrun, de seu texto "Philosophie de la Chefferie Indienne" ${ }^{\text {". }}$. Grosso modo, a chefia é um lugar particular e diferencial no sistema de trocas e de comunicações (de bens, mulheres e palavras). Ela recebe muIheres sem compromisso (embora seja obrigado à generosidade em doar 
bens materiais). Recebe bens e mulheres sem compromisso de reciprocidade; mas é obrigada a emitir um discurso interminável (por assim dizer), sem inter-locução ou qualquer dimensão performativa. Chefia = discurso sem poder. Como se o socius enclausurasse a chefia no mínimo espaço imaginável - uma espécie de "prisão". No avesso do paradoxo "obediência voluntária", o paradoxo inverso: "chefia sem poder". É claro que a exposição me impressionou forte e imediatamente. E acrescento que a expressão "Philosophie de la..." foi sugerida ou imposta por LéviStrauss. Talvez porque o texto Ihe parecesse ultrapassar a pura etnografia, caminhando já na direção de uma teoria geral da política e do Estado. $N$ a direção da estranhíssima idéia de que uma sociedade sem Estado não desconhecea essência do Estado; que, pelo contrário, écapaz de prevenirse contra sua emergência! No limite, como não há pensamento prélógico, não há paraíso pré-político. D esdea origem, o verme está no fruto.

Curioso, porquejustamentenessetexto, usando ostermos do estruturalis mo tão em voga naquela época, talvez ele dê um passo também para afas tar-se dele, não é?

D e fato, éimportante sublinhar essa deriva ou esse desvio em face da ortodoxia. Aliás, em meu prefácio $0^{5}$ insisto nesse aspecto e 0 ligo à relação permanente de Clastres com a filosofia, mesmo se a distância. Isso me é visível porque tínhamos mais ou menos a mesma idade e havíamos lido a mesma bibliografia filosófica.

N ão há duvida de que, no fim da década de 1950 e no início da de 1960, a palavra estruturalismo remetia essencialmente à obra de LéviStrauss. N ão se conhecia ainda essa espécie de ideologia, que explodiu na mídia, do fim da década de 1960, identificando Lévi-Strauss, Lacan, Foucault, Barthes etc..., obras tão distantes, em tantos aspectos, umas das outras. Tanto que em 1968, convidado a fazer uma conferência em Curitiba, comecei minha exposição afirmando dramaticamente: "não 
P. de C. Leirner \& L. H. de Toledo. Lembranças e Reflexões sobre...

existe isso que se chama de pensamento estrutural ista!". I nsisti nas diferenças radicais que separavam essas diversas obras e na riqueza que se perdia na mesmice do amálgama ideológico.

$M$ as desde sempre a obra de Clastres percorria um itinerário muito particular, mesmo em relação à ortodoxia levistrausssiana, porque jamais foi tentado a abandonar o horizonte da filosofia pelo horizonte do formalismo al gébrico (o império dos "grupos de transformação"), que havia aspirado para dentro de si a maioria dos discípulos do autor das Estruturas elementares do parentesco. Itinerário marcado pela remanência dos interesses filosóficos (como H élène, Pierre foi aluno de Gilles D eleuze, que ambos pareciam admirar muito) e pelo evidentegauchisme de que Clastres jamais se demarcou. Lembro-me de uma curiosa frase dele - de sabor kantiano -, em que dizia "a revolução é impossível, mas devemos agir como se não o fosse". Aliás eu sublinhava, no prefácio já referido, o outro aspecto dessa heterodoxia: o fato de que Clastres nunca deixou de ser um leitor da Carta sobre o humanismo de $\mathrm{H}$ eidegger. $\mathrm{E}$ não é impossível pensar a idéia das relações entre a estrutura da linguagem e a estrutura da natureza sobre o fundo da idéia da "linguagem como M ansão do Ser"...

$M$ as voltando um pouco para essa exposição no apartamento de $L$ ebrun, o que mais marcou o senhor naquela época?

0 fato de a idéia central colocar em xeque uma espécie de "evolucionismo" implícito na antropologia política, exemplarmenteilustrada, no século XIX, pela filosofia da história de Engels, que passou a fazer parte do $A B C$ do marxismo ou, pelo menos, do marxismo vulgar.

U ma reconciliação com a filosofia?

Seguramente uma relação com a filosofia diferente da que encontramos em Lévi-Strauss. Para este, passar para a antropologia era livrar-se 
de uma carga inútil. Para ele, a filosofia sempre estará ligada à filosofia praticada na universidade, ao vazio das "dissertações", em que era possível demonstrar tudo ou nada por meio de uma dialética puramente abstrata - no fundo, mera retórica. Para Lévi-Strauss tudo se passa como se a filosofia fosse essencialmente uma ilusão, ou uma forma pobre do pensamento selvagem. É o que se pode, talvez, vislumbrar num parágrafo muito curioso de Totemismo hoje. Em certo momento desse livro, ele sublinha como alguns textos de Bergson são esclarecedores para a compreensão da mitologia de uma tribo indígena da América do Norte. Esclarecedores, porque mostrariam uma afinidade profunda com essa mitologia. Bergson, penseur sauvage... Sendo capaz de explicar a mitologia, 0 antropólogo explica também a metafísica bergsoniana ${ }^{6} \ldots$

$\mathrm{N}$ o caso de Clastres, não encontramos nada de semelhante a essa arrogante diminuição da filosofia. $\mathrm{N}$ ão tinha a pretensão de escrever como filósofo - ou, pelo menos, como filósofo "profissional", setal coisa existe. $M$ as sua prática da etnografia acaba por desaguar na reflexão filosófica. É talvez por essa razão que, como vocês dizem, a obra de Pierre como a de H élène estão voltando a ser pontos de referência essenciais. Como se fosse necessário transcender, de algum modo, o estilo do "estruturalismo", para manter seu espírito mais vivo e sua permanência, para além das ondulações superficiais dos maneirismos, da moda intelectual ou da ideologia.

Talvez também o fato de que haja um movimento dentro da antropologia brasileira que pretende, a partir da dita "filosofia indígena", fornecer vi sões alternativas à própria filosofia ocidental...

Aí vocês se referem a Viveiros de Castro... Com quem, aliás, pude discutir 0 assunto numa Anpocs recente. $\mathrm{M}$ as, voltando a $\mathrm{Clastres, \text {pos- }}$ so acrescentar al go nessa direção. Certa ocasião em Pierres (sic, esse é 0 nome de uma pequena cidade, perto de C hartres, onde morei), Clastres 
contou-me a história de um discurso de certo "xamã" guarani que dizia mais ou menos o seguinte: "tudo é U m, mas isso não é bom, nós não queríamos que assim fosse". Se me lembro bem, segundo Pierre, em guarani o pronome nós tem várias formas, segundo incluam apenas os homens, ou os homens e os deuses. Diante desse enunciado, minha imaginação metafísica despertou e pensei de imediato num contraponto com H eráclito. 0 filósofo grego diz, ao contrário, mais ou menos, "tudo éum e nós devemos homologá-lo" ou ainda "é bom que tudo seja um"7. Trata-se de uma tese que é metafísica (o devir, a multiplicidade é reduzida à unidade) e ético-política (as múltiplas vontades devem submeter-seà vontade de um só). 0 bviamente, trata-se de textos de vocação essencial mente antidemocrática, que ligam a hierarquia social à ordem racional do Cosmo. Nada mais contrário ao "anarquismo" espontâneo de nossos antepassados guaranis, que aspiravam àTerra sem $M$ al, isto é, sem lè e sem trabalho.

0 correu-nos de fazer um texto a quatro mãos sobre essa oposição. $M$ as o fato éque eu não era nem antropólogo nem helenista e acabei, sabiamente, pulando fora da empresa. $\mathrm{M}$ as $\mathrm{Clastres}$ acabou escrevendo um texto curto sobre 0 assunto ${ }^{8}$. M ais tarde, uma das melhores historiadoras da filosofia grega, $\mathrm{N}$ icole Loraux ${ }^{9}$, haveria de retomar a questão, confirmando, com sua autoridade de helenista, minha intuição de amador.

D e qualquer maneira temos aí uma antecipação da contemporânea oposição entre "filosofia indígena" e filosofia ocidental.

Porque, parece que nesse texto que o senhor mencionou, haveria uma perspectiva, digamos assim, transversal entre o pensamento grego e o pensamento indígena.

Q ue eu me lembre, ele não o diz jamais explicitamente. $M$ as, se não me engano, é a conseqüência que $\mathrm{N}$ icole L oraux tira de seus textos. 
A respeito desse texto, ela realiza uma reflexão sobre o "U m" e o "D ois", porque na Terra sem $M$ al haveria uma idealização do "D ois", os homens poderiam ser homens e deuses ao mesmo tempo, e seria o contrário da pólis grega, onde elesalmejariam o "U m", ali entendido como indivisão, seguindo o princípio da Arkhé. Então haveria uma equação inversa com relação ao " $U \mathrm{~m}$ " entre os guaranis - positivo no primeiro caso, negativo no segundo...

É exatamentea idéia que me ocorreu, quando propus o trabalho conjunto com Clastres. M as é sobretudo prova de uma certa simpatia por um pensamento anarcôntico que não conjuminava muito com o estilo então dominante nas hostes do "estruturalismo".

E houve uma influência dele sobre a filosofia aqui no Brasil daquela época? Chegou a orientar al guém?

Q ue eu saiba, não orientou ninguém. M as sua influência foi notável. Influência que tinha muito a ver com sua personalidade, seu estilo inquieto, uma espécie de anarquismo não somente pensado mas vivido. Sempre foi muito avesso aos cerimoniais da universidade, mais chegado a um "boteco" do quea um seminário formal. Estilo que convergia, aliás, com minhas preferências (lembro-me dele dizer-me em 1967 ou no início de 1968: "o Fernando H enrique e o Giannotti não gostam muito de boteco, não?"; ao que respondi: "infelizmente não").

É curioso. Aproveitando que o senhor mencionou o Giannotti, de tem uma crítica forte ao Clastres, senão me engano em uma passagem de TrabaIho e reflexão, na qual diz que Clastres faz metafísica como se estivesse comendo chocolate ${ }^{10}$, al guma coisa assim...

U ma crítica muito fraca, confessemos. A despeito da complexidade da obra de Giannotti (desde a "ontologia do social" de inspiração fenomenológica atéa incorporação das idéias de W ittgenstein, passando por H egel e M arx), éimpossível - a despeito da graça de citar implicitamente 
P. de C. Leirner \& L. H. de Toledo. Lembranças e Reflexões sobre...

os versos de A tabacaria de Fernando Pessoa sobre a "metafísica do comer chocolate", como melembrou meu filho, Bento Prado $\mathrm{N}$ eto - não ver aí a resistência do pensamento especulativo (a "lógica" especulativa da posição/reposição) ao trabalho etnográfico no que tem de mais concreto e iluminador. Em Clastres não encontramos nenhuma ontologia a priori da produção. $\mathrm{M}$ as, como diria W ittgenstein, nos limites de seu trabalho etnográfico, algo de metafísico deixa-se ver ou mostrar.

Porque, no prefácio que o senhor escreve, a metafísica de Clastres já assume um valor positivo.

M ais que uma metafísica positiva, uma metafísica interrogativa. Interrogações essenciais que não poderiam emergir senão da experiência etnográfica, que seriam inacessíveis para um armchair philosopher, para usar a expressão de sir Bertrand Russell, contra os filósofos da "virada lingüística". Giannotti, que não é etnólogo, só percebe as conseqüências filosóficas do trabalho, sem se reportar à base sólida de que derivam. Sinceramente prefiro o movimento regressivo, quenos leva do fato às suas condições formais ou transcendentais. Parece-me perigoso o caminho inverso, da dedução do empírico, ou seu enquadramento autoritário num esquema prévio desenhado pela imaginação especulativa: por exemplo, al go como a "forma lógica" da práxis em sua mais abstrata generalidade. Q uando se trata de pensar sociedades ou a $\mathrm{H}$ istória, então...

0 senhor consegue perceber alguma influência que o grupo de filósofos daqui, quando ele estava aqui, teve no pensamento de Clastres, ou ele pas sou imune a isso?

Acho que passou imune. $M$ as a recíproca não é verdadeira. Como já disse, fui muito sensível às suas idéias e fiz delas o uso de que fui capaz. $M$ as sobretudo me é possível, hoje, perceber retrospectivamente como sua influência se alastrou mais largamente. É claro para mim, agora, a 
forte influência exercida sobre colegas de meu departamento, em especial $M$ arilena Chauí e Sérgio Cardoso (curiosamente, parece que os antropólogos da U SP mantiveram uma discreta distância em relação ao trabalho de Clastres). $M$ as, sem dúvida, sua influência parece atualmente ser muito maior, e não só entre os antropólogos, como provam as belas reedições de seus livros pela editora C osac \& N aify ${ }^{11}$.

Sérgio Cardoso tem um trabalho sobre Clastres, Ruy Fausto tem um pe queno capítulo dele comentando al guma coisa sobre Clastres ${ }^{12} \ldots$

$\mathrm{N}$ ão é o "D e Lévi-Strauss a M auss", não?

N ão, não é essa obra.

A memória me engana. Estou a pensar no prefácio que fiz a um livro de Ruy Fausto $^{13}$ e no capítulo sobre a antropologia, no qual percorre um itinerário diferente do de M erleau-Ponty, que escreveu seu belo ensaio sob o título de "D e M auss a Lévi-Strauss". Fazendo um percurso inverso, insistindo na amplidão do caminho aberto por M auss e sugerindo, nas entrelinhas, pelo menos, que al gumas dessas vias teriam sido fechadas por Lévi-Strauss.

E o círculo intelectual de Clastres? O s outros etnólogos..., por exemplo, o Lizot?

Jacques Lizot era amigo dele, certamente. M as jamais tive a oportunidade de encontrá-lo.

E M arcel Gauchet?

Ao que me parece, $G$ auchet era mais propriamente filósofo. Pelo menos é a impressão que tive assistindo a um curso dele em meados da década de 1990. Estava ligado ao grupo de Lefort. Tenho impressão de quese al imentava, como filósofo da política, da antropologia de Clastres. 
P. de C. Leirner \& L. H. de Toledo. Lembranças e Reflexões sobre...

$\mathrm{N}$ o curso a que assisti, junto com H élène, aliás, tratava do nascimento do individualismo no pensamento moderno e nas instituições sociais. Viajava entre a história da filosofia e a história social. D e qualquer maneira, Clastres estava ligado institucionalmente ao Laboratório de Etnologia do Collège de France.

Q ue era o Laboratório de Lévi-Strauss...

Sim, mas não sei até que ponto essa ligação institucional era propriamente orgânica...

É curioso, poisa escola sociológica francesa também é caracterizada pelo caráter coletivo da produção intelectual e ele destoa um pouco...

0 que não impede que ele tenha mais tarde colaborado intensamente com o grupo da revista Libre, liderada por Lefort, e que reunia também pessoas como Gauchet, de quem acabamos de falar, e M iguel Abensour, Cornelius C astoriadis, K rzysztof Pomian e M aurice Luciani.

E de tinha relações próximas com Lévi-Strauss?

Certamente. $M$ as não posso detalhar. D e minha parte assisti a seus cursos em 1962-63 no Collège de France, mas só vim a encontrá-lo pessoalmente uma vez em 1969. Por acaso, em 1968, Clastres pediu-me que escrevesse um artigo para uma homenagem a Lévi-Strauss, que tomou a forma de um vasto livro, publicado em dois grossos volumes ${ }^{14}$. Recebi uma cartinha de agradecimento de Lévi-Strauss, que guardo obviamente até hoje. $M$ ais que isso, a pedido de Clastres, Lévi-Strauss escreveu uma carta de recomendação ao $\mathrm{C}$ entre $\mathrm{N}$ ational de la Recherche Scientifque, quando me candidatei, no exílio, ao posto de pesquisador dessa instituição. M as minha timidez e o claro formalismo do mestre me inibiram ejamais procurei renovar contato com ele. Jamais poderia falar da proximidade dessas relações. 
Revista de Antropologia, São Paulo, USP, 2003, v. 46 № 2.

0 senhor afirma que Clastres era uma pessoa solitária. Compartilhava a experiência de campo dele com o senhor?

Solitário talvez seja uma palavra forte demais. M as certamente era avesso a grupúsculos, grupelhos ou máfias. Em nossas conversas relatava constantemente suas experiências. Comecemos pelas mais engraçadas. Certa vez, uma índia, tentando seduzi-lo, chegou a pedir auxílio a seu principal marido (trata-se de sociedadepoliândrica), que dissea Clastres que não haveria problema, que a boa ordem seria restabelecida por uma punição puramente simbólica. Ele fingi ria atingi-lo na cabeça com seu tacape, mas interromperia o gesto antes do choque. Clastres guardou a idéia da punição simbólica, mas recusou os avanços da mulher ea argumentação do zeloso marido. D uas outras histórias, relativas aos informantes indígenas: a do informante incompetente e a do informante malévolo. 0 primeiro, interrogado a respeito da palavra guarani correspondente a jamais, foi incapaz de responder imediatamente; no dia seguinte, todo alegre, trouxe a resposta, a palavra seria: "ni noticia", acrescentando "guarani legítimo!". 0 segundo, a quem Clastres perguntou 0 nome de uma ave que sobrevoava a paisagem, respondeu prontamente: "tatu". Prelibava, certamente, os mal-entendidos nos quais seu interlocutor seria enredado com esse uso extravagante da língua indígena!

\section{Ele não passou por esse desconforto simbólico...}

Jamais... 0 utra situação pouco confortável era a da luta, com osyanomami, gente muito forte. Clastres também era forte e praticava caratê constantemente (pude vêlo, nas férias que passamos juntos, exercitando-se, quebrando tijolos e madeiras com a "lâmina" da mão, que era sempre necessário enrijecer). $M$ as el e temia, entre os yanomami, que 0 bom esporte se tornasse luta real e, por que não?, mortal. Recorria então a um golpe infalível: fazia cócegas no adversário. Prática inédita que desmontava os índios que, morrendo de rir, interrompiam a peleja. 
P. de C. Leirner \& L. H. de Toledo. Lembranças e Reflexões sobre...

U ma preocupação cuidadosa com a dimensão não agonística do jogo, transformar o jogo num esporte, numa competição.

Justamente.

E quenão deixa desuscitar uma espéciedenostal gia da sociedadeprimitiva.

Pode-se falar, creio, de nostal gia. M as não se pode dizer, em seu caso como no de Rousseau, de um convite a um retorno impossível. N ão se podeler Rousseau como fazia Voltaire que, depois de ler o segundo $D$ is curso, escreveu a Jean-Jacques dizendo que já estava velho demais para voltar a andar de quatro...

Ironia, talvez?

Ironia, certamente, e formidável piada, de um grande especialista nesse gênero literário. $M$ as, também, um enorme equívoco. Voltairenão podia entender Rousseau, que explicitamente afirmava que não se pode retrogredir na $\mathrm{H}$ istória.

$M$ as, de qualquer forma, em Clastres não há uma nostal gia ingênua.

$\mathrm{N}$ ão, ao contrário. Trata-se antes de lançar luz sobre o presente de uma maneira que não é linearmente catastrofista. No caso de R ousseau talvez se possa falar de catastrofismo, já que pensa que, a partir de um certo momento, a H istória caminha necessariamente na direção de uma multiplicação da violência: a linguagem perde sua força e cede lugar à violência física. D esse ponto de vista, Rousseau opõe-se frontalmente ao otimismo da Filosofia das Luzes. A antropologia política de C lastres não dá lugar a uma tel eologia da $\mathrm{H}$ istória, quer otimista, quer catastrofista. No que não deixa de aproximar-se, pelo menos nesse ponto, de M ichel Foucault, que veio a conhecer pessoalmente no Brasil em 1965. $M$ as jamais festejou, como o outro, 0 "Retorno do espiritual em política", por ocasião do acesso de K homeini ao poder no Irã. 
Porque essa éuma outra crítica, feita por Giannotti e, se não me engano implicitamente dirigida a Clastres, que quisver na sociabilidade primitiva um excesso de igual dade, existindo um ideal ismo mui to acentuado, no qual, efetivamente, segundo Giannotti, não havia. Giannotti aponta, por exemplo, para uma desigualdade de gênero, na qual os homens ficariam com a melhor parcela do sistema produtivo, trabalho dito criativo, e as mulheres ficariam com o trabalho "menor", vamos dizer assim, porque não seria cole tivo, seria individualizado. Então ele diz: "bom, o Clastres éque pecou por projetar um ideal de comunismo primitivo onde efetivamente não havia".

Repito que acredito mais na etnografia de Pierre do que na Soci ologia Rationalis de G iannotti. Aqui quem pecaé JoséArthur que projeta o "comunismo primitivo" de Engels na obra de Clastres, que tem mil textos onde tais diferenças são descritas e explicadas. Aliás, é preciso dizer que o Sahlins, que fazia críticas parecidas - mas muito mais precisas, pois era, ele próprio, antropólogo -, insistindo também na economia das sociedades primitivas, acabou por confessar a Pierre: "no fundo, acho que é você quem tem razão".

0 senhor colocaria Clastres como um etnólogo de campo?

Q uanto isso não há a menor dúvida. Seu primeiro livro ${ }^{15}$ éa primeira evidência, trata-se de etnografia pura. M esmo quando se encaminha na direção de uma antropol ogia política, que toca os limites da filosofia política, ele sempre o faz a partir de sua extensa (vários anos) experiência de campo.

E o senhor acha que a experiência de campo para Clastres foi muito transformadora em relação à sua pessoa?

Creio que sim. Basta pensar em seu itinerário: começou fazer seu curso de filosofia em 1954 e deve têlo terminado em 1958, quando começa assistir às aulas de Lévi-Strauss e interessar-se mais pela antro- 
P. de C. Leirner \& L. H. de Toledo. Lembranças e Reflexões sobre...

pologia. Vejamos as datas [o professor Bento apanha um exemplar de A sociedade contra o Estado e passa em revista as datas e os dados biográficos]: "D urante as aulas de licenciatura começa a interessar-se por estudos etnológicos seguindo o curso de Lévi-Strauss no Collège de France a partir de 1960"16. Provavelmente assistimos juntos as aulas de LéviStrauss no ano letivo de 1962-63.

E o senhor não o conhecia ainda?

$\mathrm{N}$ ão. Como disse de início, só vim a conhecêlo no segundo semestre de 1963, no Brasil.

M as não se lembra dele nas aulas?

$\mathrm{N}$ ão me lembro, nem seria possível fazêlo. Lembro-me de que fre qüentei o curso ao lado de Fernando $\mathrm{H}$ enrique e de Giannotti. M as essas aulas eram assistidas por umas cem pessoas, mais ou menos. [E segue lendo:] "Em 65 defende sua tese de doutorado Vida social de uma tribo nômade - osíndios Guayaki do Paraguai"17. Essa tese seria transformada em seu primeiro livro. $\mathrm{N}$ ote-se que entre o começo do interesse pela antropologia e a redação do excelente livro medeiam apenas cinco anos. É a história de uma conversão, de uma mudança de hábitos que não são apenas intelectuais, que atingem a carne da vida quotidiana em sua totalidade. Provavelmente essa conversão não foi tão difícil, porque aparentemente ele sempre foi algo rebelde em face das regras que governam nosso quotidiano. Estava de algum modo preparado para uma conversão, que não é apenas do ol har ou da teoria, mas uma transformação de seu próprio modo de viver, em sua mais trivial materialidade. Contoume, por exemplo, a dificuldade que tinha no Paraguai, logo de início, em simplesmente dormir. $0 \mathrm{~s}$ índios dormiam, em noites de frio mais intenso, em volta da fogueira sem a menor dificuldade, já que espontaneamente giravam o corpo de maneira a aquecêlo de todos os lados, 
como um frango no espeto de um grill elétrico. Ele, Pierre, acordava constantemente semi-assado de um lado e gelado do outro. Só aos poucos aprendeu a técnica do que poderíamos chamar de "sono giratório". Como se vê, tornar-se etnógrafo significa, entre outras coisas, drásticas transformações de nossas inconscientes "técnicas corporais". Sem esque cer que efetivamente aprendeu a "andar na floresta". D epois desse aprendizado (que nos faz lembrar do aprendizado dos "adventícios", que se tornavam "bandeirantes" ao indianizar-se, mudando o modo de pisar, conforme a descrição de Sérgio Buarque de $\mathrm{H}_{\text {olanda }}{ }^{18}$ ), acometido de fortemalária, foi capaz de caminhar mais de $300 \mathrm{~km}$ através da floresta, para buscar o necessário atendimento médico no mundo urbano.

Por isso podemos até evocar essa inspiração maussiana em seu trabalho decampo. Eleseaproxima muito mais do refinamento etnográfico maussiano do que do formalismo derivado da obra de Lévi-Strauss.

Certamente.

I sso é uma coisa muito interessante.

Ele teve uma experiência de campo, de pura etnografia, muito mais extensa do que a do próprio Lévi-Strauss, não?

Ah, sim. Talvez, então, observando isso como reflexo na própria teoria, seria possível pensar como o suje to aparece naquela estrutura. Enfim, o sujeito dotado de vontade, esse ser social primitivo que tem uma vontade, um desejo e um temor; talvez um sujeito que ficou impresso na experiência etnográfica dele.

Eu não havia pensado nesse aspecto, mas me parece que vocês têm razão. Seguramente Pierre jamais participou do monótono coro dos profetas da "morte do sujeito". De qualquer modo, isso confirma a complementaridade entre conversão teórica e prática, entre o sujeito 
P. de C. Leirner \& L. H. de Toledo. Lembranças e Reflexões sobre...

reflexivo e o sujeito inconsciente: nada menos refletido do que as técnicas corporais...

M udando um pouco de foco, éinteressante como torna a guerra um fator positivo, tal como fica marcado nos últimos escritos dele. A guerra étomada a partir, vamos dizer assim, de sua contrapartida mais positiva para a sociedade.

Eu precisaria reler esses últimos textos. M as posso dizer como ele me apresentou a coisa. Falando dos yanomami, dizia: "aí temos uma sociedade composta de várias tribos, dividida no meio pela linha que separa amigos de inimigos, uma sociedade estruturada, enfim, em torno da guerra". 0 que melembro éque, segundo Clastres, o coeficiente de violência, envolvido na guerra, era quase igual a zero. As al deias eram cercadas por paliçadas altas e as incursões guerreiras consistiam em raras iniciativas de poucos heróis que, durante a noite, jogavam al gumas flechas por sobre a paliçada, atingindo eventual ou acidentalmente al guma criança ou al gum animal, ferindo o ombro de algum guerreiro que vagueasse pela noite. $E$ logo em seguida os atacantes fugiam o mais rápido possível para suas aldeias.

A violência eclodia, por assim dizer, fora da guerra. E ela ocorria nas festas em que uma tribo recebia outra, sua aliada, para uma festa de confraternização. Sobretudo quando os convidados eram aliados distantes. Como se 0 aliado mais distante fosse, mais que o inimigo, o verdadeiro objeto da violência social. Algumas vezes (necessariamente raras) os convidados eram atacados em meio a festa, massacrados os homens e seqüestradas crianças e mulheres. A violência era enorme, mas muito pouco freqüente, pois de outro modo o sistema não funcionaria, proibindo qualquer forma de aliança. Ela eclodia, repito, entre aliados distantes, mas sempre al iados, como sempre ocorreu em nossa Esquerda: o principal inimigo não é exatamente a $D$ ireita, mas aquele que está a sua es- 
querda ou a sua direita dentro da própria Esquerda, embora hoje utilizemos pouco as flechas e os tacapes [ri sos]. A violência é assim controlada e reduzida, mas jamais eliminada, como seria o caso numa visão idílica e nostálgica ("ideal ista”) da sociedade primitiva.

M as ao mesmo tempo isso pode ser identificado como uma contribuição paralela à reflexão dele sobre a política e o papel da chefia. Teríamos aqui uma espécie de segunda metade da moeda da teoria, que seria a guerra.

Aqui pouco posso dizer. Como já observei, não trabalhei suficientemente seus últimos textos. E tenho a impressão de que ele se aproximava de uma espécie de arqueologia da guerra quando a morte interrompeu seu itinerário. Sinceramente baseio-me mais em nossas conversas. $M$ as se você me perguntar como e onde termina sua reflexão sobre a violência e a política, responderei simplesmente: não sei.

0 senhor afirma no prefácio da Arqueologia da violência que le estava pensando em seguir al gumas investigações sobre a origem do Estado.

Isto parece estar presente em seu pensamento desde o início [toma nas mãos o prefácio à Arqueologia da violência]. Revendo meu prefácio, vejo que pensava têlo encerrado de maneira diferente. $M$ as na verdade os cuidados com as origens da guerra e do Estado se entrecruzam necessariamente: trata-se de uma mesma "arqueologia". D e resto, o título escolhido na tradução brasileira é o do penúltimo capítulo do livro. N ão me lembro do título do original.

É Ensaios de antropologia política, alguma coisa assim $\mathrm{m}^{19} \ldots$ E na convivência que 0 senhor teve com ele na França, primeiro ressaltou como 0 lado rebelde francês casou com a etnologia. $\mathrm{M}$ as como, posteriormente, 0 "Iado etnólogo" dele adentrou, vamos dizer assim, na vida do cidadão francês ocidental? 
P. de C. Leirner \& L. H. de Toledo. Lembranças e Reflexões sobre...

D igamos que ele retornou mais instrumentado para manter-se subversivo [risos].

Ele tinha efetivamente uma vida de militância política na França?

Já me referi à sua participação em maio de 1968. M as certamente esteve envolvido politicamente (se não me engano ao lado de gente como Félix Guattari) na oposição à guerra da Argélia. M as ignoro ligações político-partidárias. $M$ as não posso esquecer que chegou, nos anos 1970, a colaborar com uma enciclopédia anarquista italiana, se não me fal ha a memória.

M as ele era de família burguesa?

Certamente não de família proletária ou nobre. Seu pai era funcionário público.

Lendo o texto sobre os guayaki, a toda hora ele sugere essa idéia do medo, nas caminhadas, não sabendo o que iria acontecer... os homens brancos...

$\mathrm{N}$ ão me lembro muito a esse respeito. $\mathrm{M}$ as contou algumas histórias engraçadas. Como a de sua visita a um bar, no Paraguai, onde os fregue ses eram obrigados, como no saloon do western do cinema americano, a entregar suas armas ao proprietário. N essa visita, um paraguaio falouIhe de um assalto em que alguém teria sido assassinado pela ridícula importância de dois guaranis. "Q ue absurdo" - exclamou o narrador -, "por dois guaranis! Se fosse por vinte... ainda vá lá...".

Fiquei pensando nessa predileção de Clastres pelo caratê...

A única vez em que o ouvi falar de medo, foi quando contou como havia parado de praticar o caratê.

Era o único esporte que praticava? 
Era. Voltando à observação anterior, ele contou-me que, certo dia, quando se encaminhava para a academia, ouviu os gritos de ataque dos praticantes e estancou, de repente. N unca mais! Algo como uma súbita sensação de vulnerabilidade. Súbita e tardia, já que por volta de 1973 ou 1974. Para quem nasceu em 1934... Eu parei de jogar futebol antes dos 15 anos...

\section{N otas}

1 Professor titular do Departamento de Filosofia e M etodologia das Ciências (DFM C), da Universidade Federal de São Carlos. Bento Prado Júnior reviu o texto de suas respostas e nelas introduziu várias precisões.

2 Trata-se do texto "A propriedade do conceito: sobre o plano de imanência ameríndio", exposto no XXV Encontro anual da Anpocs, em outubro de 2001, durante a mesa "U ma notável reviravolta: antropologia (brasileira) efilosofia (indígena)".

3 Essa versão de A sociedade contra o Estado, publicada em 2003 pela C osac \& N aify, apresenta algumas diferenças em relação à edição de 1978 (pela Brasiliense). Entre elas, o prefácio deTânia Stolze Lima (UFF) eM árcio Goldman (M N -UFRJ), uma entrevista com Pierre Clastres realizada em 1974 para a revista francesa L'Anti $M$ ythes, uma rápida biografia e uma bibliografia do autor e sobre 0 autor, e uma "orelha" escrita por Sérgio C ardoso (D epartamento de Filosofia-USP).

4 "Échange et Pouvoir: Philosophie de la Chefferie Indienne", L'H omme, II, n. 1, 1962, p. 51-65.

5 Bento Prado Jr., "Prefácio", A arqueol ogia da violência: ensaios de antropologia política, São Paulo, Brasiliense, 1980.

6 O sargumentos de Bergson que Lévi-Strauss polemiza em Totemismo hoje estão na obra Les deux sources de la morale et de la religion.

7 O s fragmentos de $H$ eráclito importantes nesse caso são os seguintes: "À escuta do Logos, e não de mim mesmo, é sábio reconhecer que tudo é um" " "A lei é ainda obedecer à vontade de um só".

8 Trata-se do capítulo final de A sociedade contra o Estado. A discussão acima, na nova edição, situa-se entre as páginas 232 e 234. 
P. de C. Leirner \& L. H. de Toledo. Lembranças e Reflexões sobre...

9 N icole Loraux, "N ote sur I'Un, le D eux et le M ultiple", in M. Abensour, L'Esprit desL ois Sauvages: PierreC lastres ou une nouvelleanthropologie politique, Paris, Seuil, 1987, p. 155-72.

10 "M uitas vezes Clastres faz mais metafísica do que teoria, toma a ótica do Ser abstrato, com a simplicidade de quem comechocolate. Se existe metafísica em comer chocolate, para pensá-la convém lembrar que o chocolate precisa ser produzido antes de ser comido, e o Ser, um conteúdo para ser efetivamente pensado" (J. A. Giannotti, Trabalho e reflexão, São Paulo, Brasiliense, 1984, p. 160.

11 D epois de A soci edade contra o Estado, essa editora prepara a reedição de Arqueologia da violência. Já em 1995 a Editora 34 publicara seu primeiro livro, a Crônica dosíndios guayaki.

12 O strabalhos são os seguintes: Sérgio C ardoso, A crítica da antropol ogia política na obra de Pierre Clastres, tese de doutorado, São Paulo, D epto. de Filosofia, USP, 1989; Ruy Fausto, "Sobre a modalidade em Pierre Clastres", in M arx: lógica e política, vol. II, São Paulo, Brasiliense, 1987, p. 188-98.

13 Sob o título de "Para além da Terra prometida", prefaciei o livro de Ruy Fausto D ialética marxista, dialética hegeliana: a produção capitalista como circulação simples, São Paulo, Paz eTerra, 1997.

14 M eu artigo tinha o título de "Philosophie, musique et botanique: de R ousseau à Lévi-Strauss". 0 livro éÉ changes et communications (H ommage à Lévi-Strauss), La $\mathrm{H}$ aye, M outon et Cie., 1970.

15 Chronique des Indiens Guayaki, Paris, Plon, 1972 (publicado no Brasil como Crônica dos índios guayaki, em 1995, pela Editora 34)

16 A sociedade contra o Estado, op. cit., p. 273.

17 Id., ibid.

18 Cf. Sérgio Buarque de Holanda, Caminhos e fronteiras, 2 ed., Livraria José O lympio, 1975; em particular o primeiro capítulo "Veredas de pé posto". Aí podemos, por exemplo, encontrar a citação da saborosa referência de Tomé de Souza a João Ramalho, nosso universal antepassado: "Tem tantos filhos e netos bisnetos e descendentes delle ho nom ouso dizer a V. A., não tem cãa na cabeça nem no rosto e anda nove leguoas a pe antes de jantar" (p. 37).

19 Recherches d'Anthropologie Politique, Paris, Seuil, 1980.

Entrevista concedida em julho de 2003. 